\title{
A Political Ontology of the Pandemic: Sovereign Power and the Management of Affects through the Political Ontology of War
}

\author{
Mattias Lehtinen * and Tuukka Brunila* \\ University of Helsinki, Helsinki, Finland
}

The COVID-19 pandemic has made relevant questions regarding the limits and the justifications of sovereign power as nation states utilize high degrees of power over populations in their strategies of countering the virus. In our article, we analyze a particularly important facet of the strategy of sovereignty in managing the affects caused by a pandemic, which we term the ontology of war. We analyze the way in which war plays a significant role in the political ontology of our societies, through its aiming to produce a

OPEN ACCESS

Edited by:

Dario Quattromani,

Università Link Campus, Italy

Reviewed by:

Jenny Gunnarsson Payne,

Södertörn University, Sweden

John Lawrence Protevi,

Louisiana State University,

United States

*Correspondence:

Mattias Lehtinen

mattias.lehtinen@helsinki.fi

Tuukka Brunila

tuukka.brunila@helsinki.fi

Specialty section:

This article was submitted to

Comparative Governance,

a section of the journal

Frontiers in Political Science

Received: 28 February 2021

Accepted: 15 July 2021

Published: 28 July 2021

Citation:

Lehtinen M and Brunila T (2021) A

Political Ontology of the Pandemic:

Sovereign Power and the

Management of Affects through the

Political Ontology of War.

Front. Polit. Sci. 3:674076.

doi: 10.3389/fpos.2021.674076 unified political subject and an external enemy. Taking our theoretical cue from Butler's thinking on frames of recognizability we extend her theory through augmenting it with affect theory to argue for how the frame of recognizability produced by the ontology of war fails to guide our understanding of the pandemic as a political problem, a failure that we analyze through looking at the affective register. We argue that the main affect that the nation state tries to manage, in relation to the pandemic, through the ontology of war is anxiety. We show that the nation state tries to alleviate anxiety by framing it through the ontology war, this leads to the appearance of a potentially racist and nationalist affective climate where the "enemy" is no longer felt to be the virus, but members of other nations as well as minorities. We argue that the pandemic reveals both the political ontology of war central to the foundation of our political communities, and how this ontology is used by the nation state to manage feelings of anxiety and insecurity. Ultimately, as we will discuss at the end of this article, this leads to failure.

Keywords: sovereignty, political ontology, war, affect theory, insecurity, anxiety, COVID-19

\section{INTRODUCTION}

Across the globe, the unfolding pandemic has provoked an overwhelmingly state-centric response that seeks to deal with the negative impact that the pandemic has on a medical, social, economic, and political level. The limits and justification of political power have thus once again become relevant during the pandemic, in reaction to which the states are exerting their sovereignty in a highly visible manner. Even though the worldwide pandemic, at least at first, did not bring about institutional reforms, it definitely brought more attention to the state, which has during the pandemic been a central institution in looking after the citizens and slowing down the rate of contagion.

The traditional narrative has been that sovereignty and law are founded on violence. This has allowed scholars to make a distinction between sovereign power and biopower, which operate according to different rationalities (e.g. Oksala 2010, 38; Oksala 2013,321). Even if such a distinction 
can be made, our discussion in this article shows that a reference to violence is not enough to explain sovereignty. What we want to argue in this article is that the current pandemic has illuminated an important aspect of sovereign power that cannot be reduced to law and violence. By this, we refer to the fact that, almost immediately, the political crisis that followed the outbreak of the pandemic was enveloped in a rhetoric of war to justify strong governmental measures. This is by no means accidental. In a war-like situation-as those inciting this type of rhetoric would want it-strong coercive methods that contradict the rights of the citizens must be utilized in order to stop the political system from collapsing. As war is an exceptional situation par excellence, many who sought to justify sovereign use of power saw it as a clear analogy to the pandemic. Therefore, as we will discuss in this article, in many parts of the world March 2020 brought the problem of sovereignty into focus, or made it visible in a spectacular manner. The ongoing comparisons between the pandemic and war are perplexing. We find it unintuitive that war has in many contexts become one of the primary ways of conceiving the unfolding public health crisis. War is a political and social event par excellence, as it is a way of managing relations between differentiated political communities, and poses, in the case of a public health crisis, a questionable way of apprehending a threat that does not distinguish between communities. It is this intuition that has driven us to examine why the almost obsessively repeated comparison of the pandemic to war has been so preeminent.

In this article, we discuss the understanding of the pandemic as a "war against an invisible enemy", as Emmanuel Macron and others have described the situation. It is quite obvious, as many in the press have pointed out, that war cannot actually be fought against an entity that lacks intentionality altogether. However, the imagery of warfare used to describe the pandemic has been pervasive. For example, Joe Biden declared in a speech that the virus has "divided us, angered us, set us against one another. I know the country's grown weary of the fight, but we need to remember-we're at war with the virus, not one another" (BBC 2020). This quote brings to the forefront the reason why politicians wish to utilize this type of imagery. In a war, internal tensions and conflicts must be put aside for the time being in order to defend the nation against the enemy. To defeat the external enemy requires unity among citizens.

Our leading thought is that the pandemic is so frequently compared to war because it is a way to politically manage the anxiety caused by the pandemic by giving anxiety a referent that converts anxiety into the controllable affect of fear. As "anxiety theorists" have claimed, fear is an affect with a determinate object which means it can be controlled, while anxiety is a more unfocused affect. We propose to understand this process through Judith Butler's philosophy regarding the framing of situations through a political ontology. When a situation such as the pandemic is framed, it is drawn into different frames of recognizability that lean on different political ontologies. It is this process of framing events through different political ontologies that make them intelligible as political events in different ways. We propose that it is the political ontology of war that must be analyzed to understand how the pandemic is framed and that the friend- enemy distinction of the political ontology of war produces a specific subjectivity understood as a unified national belonging and a specific object of fear, which is understood as the non-nationals, different others, who are to be feared. In this way the state can then manage the anxiety of its subjects through closing borders, limiting movement, migration and so on. In this article, we elaborate our understanding of the political ontology of war through a reading of Thomas Hobbes's and Carl Schmitt's political philosophy. This means that we will first establish a metatheoretical framework through wedding "anxiety theory" to Judith Butler's political philosophy that we then apply on the specific political ontology of war that we analyze through reading Hobbes and Schmitt in order to understand the prevalence of the comparisons between the pandemic and war.

Our intention is not to analyze only the "discourse of warfare" as a rhetorical device or level (cf. Spadaro, 2020; Forsberg, 2020). We want to point out that by remaining only on the level of rhetorical analysis we risk sidestepping many important facets in the constitution of the political and social world. Among these facets rhetorics certainly play an important role, but we wish to stress the need for an analysis of sovereign power, which takes into account political ontology. Such an account brings out the contingency of our present political configurations and their ontological commitments. Exposing such commitments, as Johanna Oksala emphasizes, is philosophy's critical task. (Oksala 2012, 19). The discourse of warfare stems from a structure in the political ontology of communities based on sovereignty. This means that the recurring framing of the virus through the political ontology of war exposes how our way of conceiving of political events is historically and affectively conditioned by an intelligibility offered by the ontology of war.

In the first section of this article, we construct our metatheoretical argument concerning the framing of affects by political ontology through discussing the subfield of affect theory known as "anxiety theory" and Judith Butler's political philosophy. In this section, we will first discuss the role anxiety and fear play in the pandemic by focusing on how anxiety is turned into fear so as to be easier controlled or managed. We will then situate the discussion of anxiety within the context of Judith Butler's work on frames of recognizability to show how such frames are tied to a conception of political ontology in her thought. This will let us highlight how framing is tied to certain political ontologies that produce certain kinds of political subjects.

In the second section of this article, we elaborate on the working of the specific political ontology we label as the political ontology of war through reading Thomas Hobbes's and Carl Schmitt's political philosophy. We claim that analyzing the governing of the pandemic must take into account the ontological aspect of our political systems, an aspect we label the political ontology of war. War is at the very core of political communities that are based on the idea of sovereignty; it is a framework of recognizability established in order to tackle exceptional situations. Our claim is that sovereignty is defined by a political ontology of war, which allows for transposing anxiety into fear of a common enemy.

To be sure, the state's role during a pandemic has transformed multiple times during political modernity. As Foucault has 
discussed it, pandemics, such as leprosy, the plague, and smallpox, have generated different practices of governing (Foucault 1975, 228-233; Foucault 1976, 186; Foucault 2004, 11-12; cf. Erlenbusch-Anderson 2020, 12) Whereas the plague called for partitioning the city space into sectors and quarantine in some of them, smallpox called for a wholly different way of approaching health and utilizing biopower (e.g. statistical tools, vaccinations etc.) (Foucault 2004, 12; Lemke 2019, 192-193). These transformations that concern biopower, the power that has the population as an object of medical and biological practices, is distinct from the state's sovereign power (Foucault 1976, 181; Foucault 1997, 214; Oksala 2010, 36; Oksala 2013, 321; Lemke 2019, 136-137; Erlenbusch-Anderson 2020, 8). Biopower, which is not based on law in the same way as sovereign power, complements sovereign power in the sense that it allows for new areas of human life to be governed (Foucault 1976, 187-188; Foucault 1997, 219-220).

Biopower does not do away with law, but it alters and complements it with other techniques. "Biopolitical rationality", as Oksala points out, "treats the law as one administrative technique among others that can be utilized to regulate and improve the life of the population" (Oksala 2013, 322; emphasis added). Different forms of biopolitics wield biopower $^{1}$ in ways that have transformed the role of the state and its manner of governing. ${ }^{2}$ Following Agamben's famous claim that sovereign power and biopower are not distinct anymore, Sergei Prozorov claims that it "is no longer meaningful to simply oppose biopower to sovereignty" (Prozorov 2013, 191; cf. Agamben 1998 122). However, we follow Oksala in her claim that even though these two forms of power are definitely complementary and overlapping, they should still be analyzed as distinct rationalities (2010, 38, 41-42). Foucault points out that the problem of sovereignty regards both the rights of the sovereign and "the legal obligation of obedience" (Foucault 1997, 23-24). The latter refers to the role of the citizens who make up the sovereign political body (Foucault 1997, 30-31). The juridical model of sovereignty establishes the legal basis of subjectivity and the subjectification of individuals (Foucault 1997, 37-38). Similarly, even though Hobbes and Schmitt are far apart when it comes to developments in biopolitical techniques, our analysis focuses on what distinctly characterizes sovereign power and what problems it faces during a pandemic. We do not mean to deny the fact that pandemics are a concern for biopower, but, as we have seen during the COVID-19 pandemic $^{3}$, they are also a legal issue. Biopower and sovereign power are definitely not exclusive, but it is in our interest to analyze how sovereign power in both Hobbes and Schmitt relies on a political ontology, which is still relevant today and needs to be

${ }^{1}$ For the distinction between these two concepts see Erlenbusch-Anderson $(2020,8)$.

${ }^{2}$ The most extreme and well-known example is in Foucault's analysis of Nazism as the generalization of biopower (Foucault 1997, 232; cf. Oksala 2013, 323; Groulx 2015, 211). [not available in Crossref, PubMed]

${ }^{3}$ For example, in Germany reforms were made to laws concerning epidemics (in Germany, this meant the "Gesetz zum Schutz der Bevölkerung bei einer epidemischen Lage von nationaler Tragweite”) (Lemke 2020, 158-159, 182). analyzed in order to establish critical perspectives on practices of pandemic governance.

In the third section, we will discuss how the ontology of war is deployed in managing the anxiety caused by the pandemic. We will first discuss the overbearing role that the nation state has taken in leading "the offensive" against the virus, which has led to precisely the kind of mobilization of nation state subjectivity that the ontology of war produces. Second, we will draw attention to how the frame established around the pandemic by the ontology of war constantly pulls in the direction of framing the enemy, not as the virus, but as non-nationals, foreigners and migrants. The third argument we put forth is how the framing of the virus through the ontology of war can misfire in such a way that produces potential for even more anxiety, which can be seen in the increased policing internal to communities. We end the chapter with a discussion of the anti-lockdown movements, which construct the nation as an object to be feared, while still retaining elements of the kind of exclusionary framing that is emblematic of the ontology of war.

We wish to underline that the shortcomings that the pandemic reveal concerning the ontological basis of our sovereign political communities also points towards a need to overcome it. The virus is obviously not an enemy in the war-like sense of the concept, but it did not take long to locate enemies among the people. Here, we follow Judith Butler's insight that "even as the war is framed in certain ways to control and heighten affect in relation to the differential grievability of lives, so war has come to frame ways of thinking multiculturalism and debates on sexual freedom, issues largely considered separate from 'foreign affairs'” (Butler 2009, 26). As we will discuss in the third section of this article, it did not take long for politicians to blame the situation on the people of another state, whether it was the Chinese or-in the case of Northern Europe-Southern European states (cf. Rafi 2020). Locating the enemy therefore always slips into racist, hateful and exclusive categories that allow for shifting blame and drawing borders between friends and enemies.

Furthermore, our critical analysis is based on Butler's insight that, on some level, all borders between groups are fundamentally illegitimate. Our bodies, Butler insists, are not self-subsisting entities, but are "given over to others in order to persist" (Butler 2020, 49). Nobody can survive without others, and creating a limit or establishing a "frame" that separates those to be protected from "others" is always a decision that requires power to establish borders between different bodies. However, all such productions, as Butler points out, are partial $(2016,7)$. This applies to the pandemic as well. The states have strengthened their border security to limit entry, but while this obviously helped to contain the contagion, the issue of vaccine nationalism, the dissymmetry between the ability of different states to respond economically to limiting the circulation of people and goods, and other inequalities between states point towards the fact that solving the crisis triggered by the virus will require us to transcend state borders. Even if a state has brought down the infection rate to a halt, it has obviously not overcome the pandemic if the rest of the world suffers from severe stages of contagion. As we suggest at the end of this article, as social beings we are fundamentally interconnected. Following Butler's 
normative idea, interconnectedness means that ultimately the pandemic-originally meaning all (pan) people (demos)-forces us to grapple with the political ontology that is at the core of our political communities and transcend it.

\section{ANXIETY, FRAMING AND POLITICAL ONTOLOGY}

As our intention is to show how the anxiety caused by the pandemic is managed by the political ontology of war, we will in this chapter sketch out the metatheoretical lens, through which we will approach the issue. To build our chosen theoretical framework we lean on affect theory in general and the subfield of anxiety theory in particular, as it will help us understand the affective dynamics at play in the pandemic. To understand how affects are "captured" by socially and politically pre-given ways of making sense of the world, which means that they can be enveloped within certain systems of management, we turn to Judith Butler's theory for a concept of framing and political ontology. With Butler's concept of framing, we denote how events and things such as the pandemic are pulled in by political and historical shared networks of meaning, which we will denote as "political ontologies". Through framing affects in certain ways, these political ontologies then produce certain kinds of subjectivities that react to situations such as the pandemic in ways that are intelligible within the political ontology that is doing the framing. We will now first explicate our understanding of the affect of anxiety as we employ it in this article and after that we will discuss how to understand the process of managing this anxiety through linking it to a reading of Judith Butler's conception of framing and ontology.

We have chosen to focus on anxiety in particular, as we will argue it is one of the defining affects of the moment, which will help us to better understand the political dynamics of the present moment. In our analysis, we are not engaging the so-called "pandemic anxiety", framed as a medical or psychological issue (see for example Allespach et al., 2020; Liu et al., 2020; McElroy et al., 2020), but anxiety understood as a generalized social and political issue that has to do with the affective register of human coexistence. As Massumi (2015b notes 124), an affect is not the subjective content of human life, it is formed by a relational field that overflows the individual and it has to do with a collective emotional substratum lodged within coexistence. Affects are moreover formed in an unthematized way and feed on the collective memories of society that resemble those experiences that society goes through in the present moment. Affects lodge themselves into these memories and produce collective emotions that form a blend of older sedimentations and life in the present. These affects push the subject towards the future and open possible ways for the subject to act and react, which are not necessarily in line with the logic of linear time (see for example Massumi 2015a, 194).

There is a growing literature that conceptualizes the present age as affectively supercharged by anxiety. This signifies "a widespread sense of loss of control and alienation, alongside more general feelings of cultural and/or national loss," which is linked "to the significant deadly powers of nuclear weapons, pandemics, or climate change, the uncertain random violence of terrorism or cyber war, or the precariousness brought about by a weakening welfare state in conditions of globalization in the North" (Kinnvall and Mitzen 2020, 243). The role anxiety has played in relation to political events has been the object of research for example in relation to terrorism (e.g. Huddy et al., 2005), nationalism and racism (for example Hirvonen 2017) and recently in relation to climate change (for example Robbins and Moore 2013) and has begun to form its own microcosm of "anxiety theory" (see Kinnvall and Mitzen 2020, 242; Hunt 2009, 509). As an anxiety-inducing event, the pandemic has thus landed in the middle of a milieu already laden with pre-existing anxieties.

As an affect, anxiety can be characterized by being an "unpleasant and aversive state" (Eysenck 1992) that prompts the persons experiencing it to seek out a threat in their environment. However, what is important to note is that anxiety is characterized by uncertainty regarding its object (Steenbergen and Ellis 2006). Anxiety "involves uncertainty about the consequences of a threat that is not present and may not occur" (Ledoux 2016, 31). This is echoed by the way that anxiety has been conceptualized by philosophers from Kierkegaard (see Kierkegaard 1981) and Heidegger (for a discussion see Magrini 2006) to Sartre (Sartre 2007) as an affect that, in relation to fear, lacks a specific intentional object (for a discussion see Freeman and Elpidorou 2020). This definition has been reworked by Ekhlund et al. to a definition of anxiety where "the object of danger or fear is either absent/ non-identifiable, or in such a proximity that no reassurance can be offered" (Eklundh et al., 2017, 5). In our opinion, there can be no doubts about the coronavirus being a potent trigger for anxiety. The virus is a perfect target for anxiety, as it is neither living nor dead, and potentially very close or very far. Public health crises such as viral pandemics create the perfect conditions for widespread anxiety.

That public health crises are potent triggers of anxiety has been noted for example by Albertson and Gadarian (2015) who, in their discussion of the H1N1 - influenza (the "swine flu") in 2019, distinguish between framed and unframed triggers of anxiety. Unframed triggers are triggers that involve an immediate and concrete danger to life (a concrete attack by terrorists, for example) and are in this sense more general than framed triggers, which are events that have passed through a process of social coding (the War on Terror as a way to socially code terror attacks, for example). What they find is that "Public health scares often trigger widespread anxiety, whereas framed threats involve more subjective or temporally removed harms that generate anxiety for some" (Albertson and Gadarian 2015, 63). This is in line with the theoretical figure of anxiety as something that lacks clear intentionality and signifies a general precariousness and fear as something with a specific and fixed object. Anxiety thus leads to a situation where "subjects have lost their stabilizing anchor, their ability to sustain a linear narrative through which they can answer questions about doing, acting, and being," which naturally leads subjects on the path to "constantly seeking this always elusive state of perfect security" 
(Kinnvall and Mitzen 2020, 246). For our argument it is important to note that one such possibility of alleviating anxiety is through transposing "anxieties into identifiable objects of fear" (ibid., see also Kinnvall 2004). Effectively this means that anxiety is managed by giving it a common referent that identifies the object to be feared for the subject. This alleviation happens as Cossarini notes because "fears, once identified as such, can be controlled" (Cossarini 2017, 146). The objects that come to be chosen to represent the object of fear are in no way arbitrarily chosen, as Bourke (2007) and Weiss (2012) have shown. Instead, they are constituted in an evolving social-historical elaboration; the objects that get established as objects to be feared thus vary depending on socio-cultural milieu. The objects of fear are thus linked to networks of social and shared historical meaning in which the object of fear enters the realm of politics through being something that can be politically managed or controlled. We will denote these networks of social and shared historical meaning as political ontologies. It is through the process of framing that political ontologies are impressed upon things. In our case the anxiety that stems from the pandemic will become framed through the political ontology of war, which turns the unframed trigger of anxiety into the framed object of fear, subsequently to be controlled.

The affective field does not vanish when framed. Rather, it is modified, as anxiety is modified to fear, in a way that produces a certain kind of subjectivity. Thus, the attachment of any signifier to the anxiety caused by the virus can relieve it by giving it a referent. The virus is invisible, it does not offer itself as an intelligible object of fear in the same sense that the army of the enemy would do. In addition to this, we have to note that the anxiety that fear of the virus triggers is first and foremost confronted in meetings with and between people in so far as it is other people who carry the virus in their bodies and transmit it through their bodies. The virus can thus be carried by anyone, or by no one at all, which means that any human can be experienced as a threat. We clearly do not think that all our fellow human beings are enemies. It is rather the invisibility of the virus and its character as an "unobject" that causes anxiety, and which makes it possible that the object that gets chosen to be the object of fear can be localized to an infinite amount of different positions within the social world. The object which will become the nodal point to which the anxiety caused by the virus will be cathected is, as we noted, not an arbitrarily chosen object. In the case of the pandemic, it is given to us, through the frame of recognizability established by the ontology war of the nation state.

We will now shortly situate our discussion within the context of Judith Butler's political philosophy to explain how the process of framing an affective situation leans on political ontology and produces subjects that then react to social and political events framed through a certain political ontology. Here, we work with the understanding of political ontology that Judith Butler has elaborated. According to her, referring "to 'ontology' in this regard [...] is not to lay claim to a description of fundamental structures of being that are distinct from any and all social and political organizations. On the contrary, none of these terms exist outside of their political organization and interpretation." (Butler 2009,2 .) This means that the understanding of ontology that we and Butler are operating with is one which moves away from understanding political ontology as uncovering a truth about politics. Instead, we commit to an understanding offered by Markell (see Markell 2003), of which Chambers and Carver argue that it also applies to Butler's thinking, that ontology can be understood in a way "that already inflects it toward the political register: an implicit or explicit interpretation of the fundamental conditions of life in the social and political world, the kinds of things that exist [in that world], and the range of possibilities that [that world] bears" (Chambers and Carver 2008, 104). As such, political ontology simply denotes the historically constituted political things that are taken to exist, their relations, effects, and the range of possibilities that these lead to. Understood in this sense, political ontology comes to constitute a social and political network of meaning that binds together and determines the way humans structure and understand the social and political world and events that have to do with it. Natural events such as pandemics can thus be framed through the political ontologies of a given society, which constitute what Butler calls a "frame of recognizability". In Frames of War Butler makes use of this kind of notion of ontology to investigate how life becomes constituted as visible and grievable, through understanding how the production of ontology generates ontologies of the subject. Our project takes a similar kind of understanding of how political ontology influences the actor as its starting point. However, we will not look at grievability or life, but at how certain kinds of subjectivities of the ontology of war emerge during the pandemic as an answer the anxiety felt in society.

According to Butler, the frames that bring political ontology to bear on different situations produce differentiation and "organize visual experience" (one could also think of Ranciere's partage $d u$ sensible here) but over and above this, they also "generate specific ontologies of the subject" $(2009,3)$. The subjects constituted by the process of framing are according to Butler furthermore not to be understood as simply effects of power, they are a changing whole in which the reiterations of framing "produce and shift the terms through which subjects are recognized” (ibid. 3-4). Framing, or producing recognizability, thus entails that there is some kind of prior intelligibility that the framing taps into, otherwise the framing would just seem alien to us and would not move us to act as subjects. Butler importantly underscores how affects are implicated in the subject's response to events in the world, they influence our interpretation of situations: "Interpretation does not emerge as the spontaneous act of a single mind, but as a consequence of a certain field of intelligibility that helps to form and frame our responsiveness to the impinging world" (Butler 2009, 34). Affects thus exert an immediate influence over subjects that criss-cross different temporalities and are nourished by the past of social life, a past that can be understood as taking part in the political ontology of present societies. We can link the affective dimension of social life to political ontologies through the power that institutionalized frameworks of intelligibility have on individuals by referring to what Butler calls the "passionate attachments" that bind subjects to their frameworks (for a longer discussion see Thiem 2008, 37-50). Institutionalized frameworks constituting political ontologies, such as the nation 
state, work through producing subjects that reproduce the framework producing these subjects, or as Butler puts it, "frames are subject to an iterable structure: they can only circulate by virtue of their reproducibility" (Butler 2009, 24) which means that the action undertaken on the basis of these frames also reproduces the subjects produced by the frames. As Thiem notes, this Butlerian view on the reproduction of subjects means that we cannot access what subjects are outside of the frames forming them (Thiem 2008, 22). This does however not constitute a reduction of what a subject can be to a normalization of subjects conforming to institutionalized frameworks of intelligibility as the framework that "forms the subject is not an integrated and harmonious network" (Butler 2015, 44). This is to say that there are multiple possible frameworks of intelligibility and "passionate attachments" to such frameworks present in society among which some "are culturally prevalent and dominant; others are relegated to the margins" (Thiem 2008, 25). Would this not be so, critique would be constitutively blocked and we would be doomed to repeat a single political ontology ad infinitum. Hence, the Butlerian affective subject being reproduced by political ontologies comes to being as an always historical subject (for further discussion, see Shams 2020, 43-44).

\section{THE POLITICAL ONTOLOGY OF WAR}

This section analyses the basic structure of the political ontology of war, which we claim to mark a distinctive way in which sovereign political communities are constituted. Based on the theory of anxiety laid out above, our idea is to elaborate on a political ontology that brings out structures that are relevant for an analysis of sovereignty in a time of pandemic. The point is not to explain exhaustively what sovereignty essentially is-we are not analyzing the ontology of sovereignty-but to describe a political ontology of war as the basis of certain practices of sovereign power. The outcome of this section is to elaborate on a political ontology of political communities that are constructed around the possibility of war and certain practices that anticipate and counter this possibility of war-an ontology that produces specific kinds of subjectivities for the political community.

The reason why we want to analyze theories about sovereignty, and not the state as such is because we're less interested in concrete practices and institutions (such as the army) and more interested in analyzing the political ontology that produces the basis of a political community that gives legitimacy to the state. ${ }^{4}$ Theories of sovereignty claim that the state is not only a monopoly of the means of violence, but a legitimate one at that. Sovereignty, as we will point out, is about striving to produce consent to the sovereign

${ }^{4}$ For this reason, we are also talking about a subject that is different from Foucault's lectures on governing populations. We agree with Foucault that sovereignty is relevant in understanding how within a population certain things circulate (2004). In our case, it is the circulation of affects. However, whereas Foucault was interested in how populations became an object of science and power in tandem, we are more interested in the latter aspect. For example, when it comes to vaccinations Foucault is interested in the entanglement of science and regulation, whereas we are focused on the ontological basis of such political phenomena as vaccine nationalism. order. The different theories that placed sovereignty at the center of political communities believed that sovereignty needs to appear different from mere monopolies of violence. Books like the Leviathan are specifically meant to establish the legitimacy of state power. In The Social Contract, Rousseau pointed out that "a pistol in the hand [of a bandit] is also a power," but this type of power is very different from sovereign power (Book I, iii). Sovereignty, it is claimed, requires securing (at least minimal) consent of those subjected to sovereign power in order to establish its difference from a mere criminal organization. We will discuss this aspect in more detail below.

Sovereignty as a concept is about locating the basis of order within a political community, which becomes especially relevant during extraordinary circumstances. ${ }^{5}$ Theories of sovereignty deal with exceptional situations and they have been theorized under exceptional circumstances: from civil wars religious (Bodin) and political (Hobbes) to class struggles (Schmitt). Perhaps during the pandemic new theories of sovereignty will emerge-and perhaps this article will anticipate their becoming. Essential for governing during an exceptional situation is maintaining unity within the political community. Such a unity is, for practical reasons, neither absolute nor universal. Sovereign power could not operate if it had to secure complete unanimity for every one of its actions. Rather, the unity we are referring to is what founds the legitimacy of sovereign power to begin with and not specific actions. As Rousseau declares, governing might mean majority rule most of the time but, in order for the political community to be sovereign, it "assumes that on one occasion there has been unanimity" (Rousseau 2008, I, $\S v)$. Unity here then means a normative concept that seeks to limit civil unrest to a minimum. ${ }^{6}$ As Schmitt claims, "plurality" within a state becomes something that can only be tolerated to the extent that it does not destroy the political unity (Schmitt 1932/

${ }^{5}$ The exceptional is always potential or else the justification for sovereign power within a civil society would become void. This means that state of nature (or exception) is never fully resolved, because if social negativity were to be overcome completely, the need for sovereignty would cease. This reciprocal role of the state of nature creates a difficulty in interpreting sovereignty's relationship with the state of nature. Agamben's interpretation is that the "identity of the state of nature and violence [...] justifies the absolute power of the sovereign" (Agamben 1998, 35). According to Sergei Prozorov, one prominent line of interpreting this issue-most notably by Agamben and Esposito-is by interpreting it so that there is always a "remainder" of the state of nature within society that cannot be transcended completely (Prozorov 2015, 59). Hobbes, in particular, is an "illustrative or striking example of a tendency in modern political thought to constitute and legitimize authority by conjuring the negativity that it then interprets as natural and seeks protection from" (Prozorov 2015, 58; cf. Helmisaari 2020, 23). The fiction of the state of nature is meant to give legitimacy to the sovereign, and as a fiction, it is not natural but a potentiality that establishes the justification for sovereignty (Helmisaari 2020, 63). Therefore, as Agamben claims in Homo Sacer, potentiality is essential to sovereign power (Agamben 1998, 46-47). According to Derrida, 2005, this "allows at one and the same time for war to be waged at the political's condition of possibility without it being for all that, in any respect, the aim, the finality or even the content of the political" $(2005,126)$.

${ }^{6}$ In The Social Contract Rousseau writes that "the sole means that they still have of preserving themselves is to create, by combination, a totality of forces sufficient to overcome the obstacles resisting them, to direct their operation by a single impulse, and make them act in unison" (Book 1, vi). 
2015, 42). According to him, the methods the state has at its disposal are essentially instituted for the function of "making uniformity possible and its daily restoration" (Schmitt 1928/1995, 37). Obviously, the sovereign's strive towards unity can practically never be complete, but it is still central to legitimizing its practices that try to minimize protests and dissent.

Our argument is that transposing anxiety into fear is a crucial mechanism in producing and upholding this type of original unity. In order to achieve this, we elaborate on a political ontology that is centred on war. This is not an analysis of war and its ontology, but a political ontology centred on the possibility of war. During a war, the citizens must remain unified against the enemy. A political community, to hold the enemy at bay and deter a war from happening, must also remain unified in a pacified situation. Similarly, slowing down the pandemic necessitates the citizens to consent to the methods being used to slow down the rate of infection. We will elaborate on this political ontology by analysing its role in theories of sovereignty. Hobbes is obviously crucial here but so too is Carl Schmitt, the legal theorist who introduced the problematic of sovereignty into the 20th century and who infamously claimed that the political is the distinction between friend and enemy. We will first look at Hobbes as the basis of a theory of sovereignty and how anxiety relates to it. A similar study in a much more extensive manner has been done by Bahar Rumelili (2020), who argues that anxiety is central in Hobbes's understanding of the state of nature. Next, we analyse Schmitt's theory of the enemy as a paradigm example of how enmity is crucial for a political community.

The state of nature as the war of all against all is not a state of constant fighting but the "disposition" to do so. As there is no common power to prohibit fighting it is always a potential possibility, so that "every man is Enemy to every man." (XIII, $\S$ 62.) The problem that individuals face in a state of nature is not that life is constant fighting but the lack of trust towards others. Since all are equal in capacities in a state of nature, it is not specific individuals that cause the lack of trust as the feeling of uncertainty is constant. Even those who would otherwise be content with modest means, Hobbes claims, will have to amass more power simply for their own security (XIII, $\$ 61$ ). Lack of trust and the experience of insecurity forces people to remain in the disposition of war, which is not directed against anyone in particular. Such a situation can be best analysed through our analysis of anxiety. As Ruhelili writes, 'the 'perpetual fear' generated by the unknowability of the future and limits of human knowledge make not only self-preservation at present, but also the foresight of future self-preservation an ultimate concern" $(2020,263)$. In a state of nature, the experience of uncertainty and insecurity is constant and it has no specific object that would cause it. Hobbes writes precisely that in a state of nature there is no "common Power to feare." The sovereign is that power which establishes consent through fear, that is, manages anxiety by framing it into fear of punishment.

However, it is not only fear of the sovereign that frames anxiety. What is so crucial about defining war as a disposition is that it basically means that even when there's no fighting, a war might still be taking place. ${ }^{7}$ As Hobbes claims, the state of nature does exist between states, so that they are "in continual jealousies, and in the states and posture of Gladiatiors; having their weapons pointing, and their eyes fixed on one another" (Hobbes 2018, XIII, $₫ 63$ ). A disposition to fight remains between states, and it is this disposition that the citizens should be aware of at all times. As commentators have pointed out, this allows Hobbes to further his argument of strengthening the power of the sovereign (cf. Tuck 2001; Poole 2015; Koskenniemi 2017). The existence of enemy states necessitates certain capacities, such as collecting taxes for maintaining an army. More important for our argument, however, is that the existence of an external enemy establishes uniformity within a political community. As Hobbes writes, the objective of the institution of sovereignty is "the peace of the subjects within themselves, and their Defence against a common enemy" (Hobbes 2018, XXI, \$ 111). Without a common enemy, according to Hobbes, the citizens would become restless and fight against one another. It is not only the sovereign that the citizens must fear but the enemy as well. The sovereign, in order to maintain stability, must frame the anxiety of the citizens into a fear of an enemy that is external to the community. The sovereign therefore externalizes mistrust among citizens into an enmity towards another state. It is precisely this type of externalization of anxiety that frames it as fear of a specific object that legitimates sovereign power. ${ }^{8}$

Theories of sovereignty tend to link violence and power together, if not completely equate them. ${ }^{9}$ Without sovereign power, there is no order that would limit the disposition to fight. (Hobbes 2018, XIII, $\$ 62-63$.). Coercive power is essential because words alone are not enough to create obligations (Hobbes

\footnotetext{
${ }^{7}$ Further, Nordin and Öberg (2015) criticize theories that equate war with the concrete event of fighting.

${ }^{8}$ The need for security implies a state of insecurity that justifies the establishment of a political system. As Achille Mbembe succinctly summarizes this, "the security state thrives on a state of insecurity" (Mbembe 2019, 54). Rousseau - another theorist of sovereignty - puts it thus: "What is the purpose of political association? The security and prosperity of the associates" (Rousseau 2008, III, $\$$ ix.) There is definitely disagreement among different theories of sovereignty. One example is the famous disagreement between Hobbes and Rousseau concerning what constitutes security and what kinds of powers can be justified. Notwithstanding these differences, as Frédéric Gros elaborates, both Hobbes and Rousseau are in unison about the centrality of the concept of security in their political theories, and about the essential difference between the state of nature and civil state (Gros 2019, 75). Similarly, our point is to bring out a basic understanding of the political ontology that is essential to political communities of sovereignty-not to analyze the finer details of these thinkers. "Security," Gros emphasises, "is simultaneously as the principle of the state's foundation, the ultimate cause behind civil societies, the source of legitimacy for the authorities, and the objective of instituting political communities" (Gros 2019, 76). Security then justifies both the institution and the constitution of a state and allows for evaluating the state's functioning.

${ }^{9}$ Because of the obvious authoritarian implications of this link, Arendt makes a clear distinction between power and violence so that "power springs up whenever people get together and act in concert, but it derives its legitimacy from the initial getting together rather than from any action that then may follow." This means that consensus creates power, but the power over means of violence can never reflectively create consensus (Arendt 1969, 37, 52-54.). Derrida's succinct description is worth quoting here: "The abuse of power is constitutive for sovereignty" (Derrida 2003). Similarly, Joan Cocks, 2014 discusses sovereign
} power as a form of "foundational violence" (47ff). 
2018, XIV, \$ 63-64). “Covenants, without the Sword, are but Words, of no strength to secure a man at all" (Hobbes 2018, XVII, $\$ 85$ ). Without coercive power, everyone is in a situation to "make warre upon each other for their particular interests" (Hobbes 2018, XVII, $\$ 87$ ) because in a state of nature nobody has any reason to fear punishment for misdeeds (XVII, $\$ 85-86$ ), whereas in a state the sovereign has coercive means to force people to hold on to their covenants (XIV, $₫ 71$ ). The only way to establish a Commonwealth, which is able to defend from invasion and injury, is to transfer all power to the sovereign who will "reduce all their Wills, by plurality of voices, unto one Will", that is, to form the sovereign is to submit will and judgement to the sovereign (Hobbes 2018, XVII, $₫$ 87). Following this formulation, sovereignty is about interpreting power as coercion, of which Foucault summarizes succinctly that "law is always referred to as a sword" (Foucault 1976, 189).

It is true that the state has a power over its subjects' lives due to its monopoly on legitimate means of violence. To quote Schmitt: "The state as the substantial political unity has an immense power concentrated in itself: the possibility to lead a war and thereby usually to command over the life of the people" (Schmitt 1927/ 1988, 70; Schmitt 1932/2015, 43). ${ }^{10}$ When it comes to the internal issues within state territory-and this is crucial-the state has complete powers to ensure "peace, security and order" and therefore to "establish the normal situation." (Schmitt 1932/ 2015 , 43.) Therefore, sovereignty is about establishing a space within which internal conflicts become de-legitimized. This is due to the fact-which Agamben would describe as "thanatological" and Mbembe as "necropolitical" (Agamben 1998; Mbembe 2019; cf. Balke 2005; Oksala 2013, 321) - that the sovereign has the right to sanction and punish those unwilling to limit themselves.

However, we are neither interested in a general discussion regarding security nor in looking at sovereignty merely as a centralization of the means of violence. In order for a state to be sovereign, a lot more than weaponry is required. Unlike Foucault's summarization in the quote above, law is not based on mere coercion but those subjected to it need to consent to it. This requires specific forms of subjectivities and therefore an analysis of security must also take into account the context of framing affects. The casting of the feeling of insecurity is central here. Sovereignty is not established merely through violence but through a political ontology that wards off anxiety. As Rumelili points out, even for Hobbes fear needs an object and therefore it is produced politically (Rumelili 2020, 263). Here, we analyse giving anxiety an object or referent, that is, an enemy, based on which a political ontology of war transposes anxiety and the feeling of insecurity into a fear that then legitimates the existence of a sovereign. Once anxiety is framed as a fear of an object, that is the enemy, what emerges is subjectivity that consents to state power, thus making it sovereign. As we will point out below in this section, the possibility of war is what frames these affects.

As we pointed out above, sovereignty is connected to producing consent to political power. From the perspective of

${ }^{10}$ As Foucault points out, theories of sovereignty posit sovereignty as a power that unites and as the "unity of power" (Foucault 1997, 37). those who wield sovereign power, the lack of dissent or, at the very least, limiting it to a bearable minimum, allows for the smooth functioning of its practices. What sovereign power needs is to manage dissent to a minimum that is bearable. In order to do this, sovereign power has to at least appear as if it was based on some form of consent. This does not mean a constant need of unanimity but, instead, using a very weak form of consent as a way to delegitimize all who oppose the operations of sovereign power. Theorizing politics through the concept of sovereignty, to quote de Lagasnerie, "essentially works by countering protest movements and mobilizations by reminding them of the political order" (de Lagasnerie 2020, 59). Violence used by the state and against it are both forms of violence, but from the perspective of sovereign power state violence is legitimate because it is used to minimize illegitimate violence. As Katrin Meyer points out, "the socially destructive force of violence becomes a normatively justifiable praxis only when it can legitimize itself as violence against violence" (Meyer 2016, 51). For distinguishing between legitimate and illegitimate violence, as we will point out next, consent needs to be defined in a weak sense.

Hobbes's understanding of consent, which is crucial for our argument, is that covenants that have been agreed to under fear are valid (XIV, § 69). ${ }^{11}$ Humans act in order to gain something or avoid harm, and therefore to avoid something out of fear is consistent with an individual's will (XXI, $\$ 108$ ). The political order and its maintenance necessitate that subjects limit their freedom as humans, because "as long as every man holdeth this Right, of doing any thing he liketh; so long are all men in the condition of Warre" (Hobbes 2018, XIV, \$ 65). The establishment of the commonwealth and sovereignty means the creation of an obedient subject that is willing to limit itself for the sake of political order (XIV, $₫ 65$; XVI, $₫ 79-80$ ). The state of nature produces consent and agreement, because "all men agree on this, that Peace is Good and therefore also the way, or means of Peace" (XVI, $₫ 80$ ). To be a citizen therefore is to act according to the different obligations such as not to dissent, in order to secure peaceful coexistence. It is true, to quote Foucault, that consent in this context can be interpreted as the preference to favor life over death (Foucault 1997, 82). Whereas in a state of nature, where nobody had any reason to fear punishment for misdeeds (XVII, $\S$ 85-86), in a state the sovereign has coercive means to force people to hold on to their covenants (XIV, $\$ 71$ ). However, to understand how consensus is established, an analysis of the "thanatological" or "necropolitical" aspects of sovereignty is not enough, as we have pointed out above. Instead, the sovereign must frame anxiety as fear of an external enemy.

\footnotetext{
${ }^{11}$ Here we agree with Foucault's idea that the Leviathan's core idea is that the fact of civil society reigning and the state of nature not being at hand means that subjects have consented to the covenant. The possibility of the state of nature, therefore, provides a valid consent that legitimizes sovereignty (Foucault 1997, 84-85; cf. de Lagasnerie 2020, 61.). Foucault's idea is therefore that the concept of the state of nature allows for de-legitimizing rebellion, and to claim that not rebelling implies consent (Foucault 1997, 83-84; cf. Hobbes 2018, XX, $\$ 103-104$; de Lagasnerie 2020 , 57). Similarly, Schmitt claims that the only reason to submit to somebody is security and protection through power. "Who looks for protection and accepts it, does not have to right, to refuse obedience." (Schmitt 2017, 14.)
} 
This brings us to the political ontology of war, which refers to how the legitimacy of this subjection is established. The political ontology of war is not an ontology of war as an event, but an ontology of sovereignty and its justifications that are founded on the possibility of war. As Schmitt points out, "war is neither the aim nor the purpose nor even the very content of politics. But, as a real possibility, it is an ever-present presupposition [Voraussetzung], which determines in a characteristic way human action and thinking and thereby creates a specifically political behaviour." (Schmitt 1932/2015, 33; cf. Kennedy 1998, 101.) the possibility of war is essential to the political as such. Therefore, this means that war itself is not the content or the aim of politics, since war is only a means to reach a certain goal, but, rather, it defines the structure of the political as such.

This is what brings us to Schmitt's definition of the political as the distinction between friends and enemies (Schmitt 1927/1988, 69; Schmitt 1932/2015,26). War establishes specific forms of vertical and horizontal relationships. A political unity assumes (setzt voraus) the real possibility of an enemy (Schmitt 1932/2015, 50). The political is about the possibility of a concrete political formation. As Schmitt states, the political is the "real possibility of grouping friends and enemies", that is, "based on the power of [the political unity's] decision, the real possibility in a certain situation to determine the enemy and fight against it" (Schmitt 1927/1988, 69; Schmitt 1932/ $2015,42)$. The actuality of a political unity is based on the possibility of war, so that if this possibility were to be removed, that is, "when the real possibility of struggle is ruled out and every friend and enemy grouping has become impossible" (Schmitt 1927/1988, 73; Schmitt $1932 / 2015,33,52)$. The enemy is someone against whom "in extreme cases a conflict is possible" (Schmitt 1932/2015,26), so that the enemy becomes an opponent and not merely different in some lesser sense. The enemy is always a public one - "a private citizen has no political enemy" (Schmitt, 1927/1988, 72) - because only the political unity has the strength to make that distinction.

The contradiction between the political unity and its enemy has to be understood in the context of war. Not all nations, Schmitt points out, are capable of waging war and therefore they are no longer political in the proper sense. The political unity is properly political only when it has the possibility to engage in warfare against its enemies. (1927/1988, 69-70; cf. Pankakoski, 2017, 657-658). In a civil war, if the contradiction between internal opponents becomes so intense that no one is strong enough to take over the capacity to decide over war and peace, then the political unity ceases to exist. Either there is a force that is capable of establishing a political unity, which means having the means to fight against an enemy and being strong enough to distinguish between friends and enemies, "or [the political unity] is in general not at hand." (Schmitt 1932/2015, 37; cf. Kennedy 1998, 100.) Here, many scholars have pointed out that Schmitt's background in establishing this definition of the political comes as a reaction to the Versailles treaty's limits to the Weimar Republic's sovereignty and his attempt to argue for national unity in the face of domestic political tensions (cf. Balakrishnan 2000, 114; Kennedy 2004, 106-107; Kervégan 2011, 176-179). An enemy is therefore central to producing national unity. This means that the distinction between friends and enemies dictates that conflicts among friends can never be legitimate because they would threaten the capacity of the political unity to fight against the enemy. To go against this distinction, Schmitt emphasizes, means to "place oneself in the order of things on the side of the enemy" (Schmitt 1932/2015, 49).

There is nothing extraordinary about this interpretation of Schmitt's theory of the political. ${ }^{12}$ Mouffe (2005), for example, describes the Schmittian idea of the enemy as the "constitutive other" of a political unity. Without exclusion - the idea claims there is no identity. However, what we wanted to point out was that the Schmittian distinction is one that produces unity through the possibility of war. The sovereign, with the capacity to wage war, upholds the unity among friends in order to defend against the enemy. It is the existence of the enemy that necessitates unity. As we have already analyzed, the fear of the enemy is central to producing this unity. Internal conflicts and exceptional situations must be deterred in order to remain unified against the enemy. This is the main take-away that we get from Schmitt's attempt to defend state sovereignty. War is at the heart of political communities and evoking it means to uphold unity and produce consent. Therefore, the enemy is designated to govern effectively and ward off internal tensions.

The issue with the political ontology of war is that the uniformity of citizens is achieved by turning them against an enemy. As has been evident during the pandemic, for many it was not the virus that was the enemy, but some other group of people who are allegedly irresponsible when it comes to slowing down the pandemic. A notorious example was the former president of the United States, Donald Trump, who infamously called COVID-19 a "chinese virus" (Liu 2020; Rafi 2020). We will discuss this in more detail below but let us state here the obvious and say that an enemy is not a necessary requirement for mutual cooperation among the citizens.

The pandemic as an exceptional situation is, of course, not completely unique. The pandemic is not the event that has finally made us realize the political ontology of our political communities. Instead, similar types of framing do take place in other exceptional situations as well. For example, in the "war against terror" after the 9/11 attacks similar framing of affects can be seen. Joanne Esch has analyzed how in the political discourse after the attacks the rhetoric of war seeks to establish a traditional civilization vs barbarism -distinction in order to normalize and legitimize certain state actions (Esch 2010, 386; cf.; Ditrych 2013). Similarly, based on Arendt's political theory, Elizabeth YoungBruehl makes a point similar to ours that the attacks in 2001 were "immediately analogized to Pearl Harbor. In a flash, the American people were encouraged to assume that the American response should be war, as though al-Qaeda were a nation state like Japan." (Young-Bruehl 2008, 13.) ${ }^{13}$ The anxiety caused by terrorism was managed by locating a public enemy, against which a war could be waged. As Scheuerman points out, the discussion regarding Schmitt's ideas was revitalized after the

\footnotetext{
${ }^{12}$ For a detailed discussion of Schmitt's understanding of war, see Pankakoski (2017); Teschke 2016.

${ }^{13}$ Also from the Arendtian perspective, Joan Cocks writes from the Arendtian perspective on how traditional ideas regarding sovereignty were present in USA's war on terrorism as "an actual war against a weak sovereign state as a substitute for its shadowy antagonist” $(2014,24)$.
} 
start of the war on terror (Scheuerman, 2017, 560-561). However, our point is not to say that the pandemic has once again made reading Schmitt relevant, but that sovereignty as a concept that is distinct from biopolitical considerations should once again become a relevant object of inquiry. ${ }^{14}$

Lastly, the political ontology of war is about the management of affects relevant to the unity of the political community. Hobbes infamously claimed that the sovereign must have power over the intellectual doctrines within a state. For the sake of security, the sovereign must produce consensus. Schmitt notes that there can be unity through both power and consensus. "Real power produces true consensus and true consensus produces true power." (Schmitt 1933/1958, 370.) However, Schmitt sees it so that during exceptional times when the political unity is threatened the former is preferred. The central question then becomes, who is the sovereign that has the authority to uphold unity during an exceptional situation (Schmitt 1930, 35.) As we claim below, this means that the sovereign must rule over and manage the political affects of the citizens. As Schmitt claims, humans are susceptible to affects and therefore in need of governing to remain united $(1932 / 2015,55)$.

Therefore, to conclude, the political ontology of war is about recognizing the differences between subjects. As Butler points out, the logic of war functions at the basis of our political communities to "distinguish lives worth safeguarding from those that are not-populations conceived as collateral damage, or as obstructions to policy and military aims" $(2020,62)$. This ontological aspect is based on establishing war as a potentiality, which then justifies certain institutions and exclusion of certain subjects from those that are to be protected. Important here is the concept of the enemy, the definition of which is supposed to help distinguish those subjects that are under the protection of the sovereign. We want to analyze the ontological and affective aspects of this issue to better understand the basis of the utilization of the rhetoric of war during the pandemic. To wage war against the virus means to demand the political community to act together and unanimously to defeat its enemy. For example, Macron has called on unity among citizens in the face of the war against the virus (Le Monde 2020) and massive state-sponsored informational campaigns around the globe have interpellated citizens to act responsibly and in a unified manner. The political ontology of war is therefore a way to identify differences between subjects, to counter those subjects that have been deemed on the side of the enemy, and, lastly, to establish a necessity for uniformity among citizens.

\footnotetext{
${ }^{14}$ This means to go in a different direction than Catherine Malabou or Falk, who both discuss sovereignty and biopolitics in tandem (Malabou 2015; Falk, 2011). As Agamben would put it, "the production of a biopolitical body is the original activity of sovereign power” (Agamben 1998, 7).
}

\section{DEPLOYING THE POLITICAL ONTOLOGY OF WAR ON THE PANDEMIC}

To sum up our discussion so far, we have argued for understanding the virus as an event that produces anxiety, which is then framed through political ontology to give the anxiety a referent, which turns it into fear, an affect that can be controlled and managed. We then attached this managing of anxiety onto a political ontology that we analysed in the context of sovereignty. Framing anxiety as a fear of the enemy, as we pointed out, is central to sovereign power in general. Therefore, our argument is not that the COVID-19 virus has once and for all revealed the essence of sovereignty because the framing of affects we have described is neither novel nor unique to governing during a pandemic. Instead, we argue that understanding the production of consent in the context of sovereignty tells us something about how our political communities operate during a pandemic that biopolitical analyses might leave out.

Sovereign power, according to Foucault, can be formulated as the right to take lives or to let live ("le droit de faire mourir ou de laisser vivre"). (Foucault 1976, 178.). "Law cannot be nothing but armed, and its weapon, par excellence, is death; for those who transgress it, law responds with this absolute threat, at least as a last resort. Law always is referred to as a sword." (Foucault 1976, 189). However, even if sovereign power might be in some ultimate sense reducible to violence, our discussion above has shown that a reference to violence is not enough to explain sovereignty. As we pointed out, framing produces a particular kind of political subjectivity. The political ontology of war constitutes the very specific form of framing and a concomitant ordering of social relations in our societies. Here, war does not refer to an actual event, but forms a central part of the political ontology that is being called on in framing the pandemic. The possibility of war establishes a demarcation between those subjects that are friends and those that are not. Schmitt claims that the political unity is "definitive" in that it defines the people that take part in it. The political unity (i.e. a state) upholds the distinction between friends and enemies and, therefore, upholds the definitive identity of friends, too. (Schmitt 1932/2015, 28, 41.). The existential threat of the enemy necessitates that certain political structures, hierarchies, exceptional measures and so on, are instituted to ward off this possibility.

In this part, we will discuss how the ontology of war is deployed in managing the anxiety caused by the pandemic. The first phenomenon we wish to note is the overbearing role that the nation state has taken in leading "the offensive" against the virus, which has led to precisely the kind of mobilization of nation state subjectivity, that the ontology of war produces. The second phenomenon we wish to draw attention to is how the frame established around the pandemic by the ontology of war constantly pulls in the direction of framing the enemy, not as the virus, but as non-nationals, foreigners and migrants. The third phenomenon concerns how the framing of the virus also misfires in such a way that produces a potential for even more anxiety, visible in the increased policing internal to communities. We close this section with some remarks on the anti-lockdown protests, which manifests a framing that seems to lean on other frameworks that try to alleviate the anxiety of the pandemic by framing the state to act as an object of fear in different ways. In Butlerian terms, the virus escapes a certain "recognizability" that the political ontology of nation state 
constitutes, as recognizability crafts a "living being into a recognizable subject, though not without errancy or, indeed, unanticipated results." (Butler 2009, 5.) As the nation state constitutes a frame of recognizability through its production of political ontology it also produces, as Butler notes, errancy or unanticipated results, as well as dissent. The errancy of the recognizability in relation to which the nation state construes the position of the subject and the virus can be understood as the "misfiring" of the framing of the virus by the nation state, which leads to heightened anxiety.

As we have argued, anxiety can be understood as a widespread sense of loss of control, it is felt especially in the face of situations where the object that causes a feeling of losing control is hard to locate. It is in the first place the threat to life that the virus poses, and especially its hidden and potentially omnipresent character, that causes anxiety. This is further strengthened by the material consequences of the pandemic, financial, and social. The anxiety that the pandemic gives rise to is ultimately based on the unpredictability of its transmission. The pandemic has made the concept of infection a political phenomenon. This means trying to fit the spread of the disease into a symbolical frame that operates by relieving the anxiety related to its uncertainty (cf. Lohm et al., 2015). Here, our argument is that anxiety caused by the pandemic is a serious issue for sovereignty. In order to manage anxiety, secure social relations and avert internal conflicts, the state needs to govern affects and ensure uniformity.

During the global pandemic in 2020, in most parts of the world, the state has put itself in the position of the political institution responsible for managing the pandemic. ${ }^{15}$ This is made very clear by how strongly states have exerted their political powers by closing down borders, limiting migration, business and the freedoms that citizens normally enjoy in Western societies. In an exceptional situation, as Schmitt would have it, the sovereign reveals itself (Schmitt 1921/2015, 13). In relation to preceding contemporary pandemics such as the H1N1, SARS, MERS, Ebola, HIV-AIDS pandemics, or in relation to historical pandemics such as the Spanish flu or the Black Death, the COVID-19 pandemic has been, as Woods et al. argue, handled as "a direct function of nationalism" as "none of the previous pandemics involved worldwide lockdowns, cessation of normal activities and massive state sponsored and state-controlled mitigation" (Woods et al., 2020, 811). What the pandemic seems to have revealed was that the contemporary role of protecting citizens still belongs to the state. However, as we have pointed out, it also revealed a central imaginary nexus in our understanding of political institutions in the form of the political ontology of war, with the need for the unity of the citizens that we have already discussed. The ontology of war offers the state an essential tool in securing a "strong national identification as their state assumes the major responsibility to protect them during a crisis" (Su and Shen 2021, 171. See also; Bieber 2020).

Within the nation state's frame of reference, warfare is talked about precisely in terms of the valiant sacrifice that citizens do for the common good. As Schmitt would have it, political unity demands the "readiness to die and to kill" (Todesbereitschaft und

${ }^{15}$ Regarding the pandemic and the state in the context of human rights treaties, see Chia \& Oyeniran (2020).
Tötungsbereitschaft), or else it is not political in the real sense (Schmitt 1932/2015, 43). The war against the virus therefore produces a certain level of unity between citizens and seeks to influence our way of acting in society, thus it seeks to limit ways of acting that could be perceived as dissenting in relation to the employed framing. The political ontology of war is certainly not the only ontological founding that could produce the desired action and manage our anxiety within the frame of reference provided by the nation state, save for the ontology of war that we have analyzed here. ${ }^{16}$ However, it has certainly become central for a reason. The kind of management of anxiety that the ontology of war does produces hierarchies and obedience. In this style, Donald Trump talked about himself as "a wartime president" (White House, 2020). The Prime Minister of the Chezch Republic, Andrej Babiš, "seized every opportunity to stress that the nation was fighting a war" (Kleio in Pandemia 2020) and the Greek Prime Minister Kyriakos Mitsotakis remarked that "we are at war with an enemy who is invisible" (Reuters 2020); many more examples could be summoned. Obedience in war means adjusting one's own behavior to accommodate collective needs. War thus works through producing unity because of the historical structures of the nation state. In the name of what other event than war, could Macron demand "full mobilization" (Le Monde, 2020)? Similarly, during his presidency Trump urged that "every generation of Americans has been called to make shared sacrifices for the good of the nation," which he then likened to the sacrifices made during the Second World War (The White House, 2020).

It is important to note that there is variation in the responses to such authoritative acts of framing, both within the population and across populations. As was noted in the first section of this article and above, there are different frames and political ontologies present in and between societies, which effectively means that there can be political contexts where the framing of the pandemic isn't present to the extent it is in certain contexts (Sweden is sometimes used as an example of such a context, see for example Strang 2020; Dagens Arena 2020). It also follows that in different contexts where the political ontology of war is used to frame the pandemic, there will be differing levels of mobilization and unification enacted in its name as well as differing levels of dissent in relation to the framing (e.g. the case of Trump provoked a backlash, see Kleiner 2020; Washington Post 2020).

The affective subject called on by the ontology of war is naturally not performed into being solely on a command issued by the leader of a nation, instead it has to tap into the collective political ontology of society, its historically constituted memory and way of understanding itself, to bring about the kind of national subjectivization that the pandemic has done. For example, in Finland this has been done by tapping into "the memory of the bloody civil war, the role of both external and internal threats to the existing societal order during the post-World War II years, and the longstanding state-

\footnotetext{
${ }^{16}$ As Alyeksyeyeva et al. write, "in times of crises, war rhetoric appears the most persuasive and appealing tool to influence the collective mind of the public, since militarisation of crisis discourse helps to restrict the recipients' conceptualisation of the situation to a war frame as well as undermine or marginalise other conceptual representations of this crisis" (Alyeksyeyeva et al., 2021, 98).
} 
orchestrated efforts to construct a coherent nation state" (Moisio 2020, 600). For example, Sjölander-Lindqvist et al. $(2020,10)$ have discussed such examples in the German and Italian context of the pandemic response, where "historical references are made to install a sense of community, and they all embrace the notion of active citizenship through pointing to the role the individual plays for the common good". The collective memories created by these kinds of historical understandings work together with the ontology of war to mobilize national subjectivity, they give collectively recognizable and affectively binding substance to the framing.

The effort of constructing the subjectivity of the ontology of war is also echoed clearly by sentiments of national pride that underscore the fruits of the national struggle during the pandemic, statements such as that made by Italy's prime minister Conte, who said that "Italy, we can say it loudly, with pride, is proving to be a great nation, a great community, united, and responsible" (quoted in Sjölander-Lindqvist et al., 2020,6). Appeals to the specifically excellent character of the people of the own nation state have been circulated in a host of national contexts, such as the Danish prime minister's calls that Danes "are made of particularly strong material and have a unique ability to act driven by a sense of solidarity with other Danes" (Villadsen 2020, 230). These appeals could obviously only work against a shared background of understanding, where being of a certain nationality constitutes a substantial mode of political identification.

The central problem with the political ontology of war as a way to manage anxiety and establish uniformity is that it leads to a feeling of hate against different groups of people, and which can only be described as racist (Liu 2020; Rafi 2020). To manage anxiety, the ontology of war seems to transfer the target of the affect from the virus to another people to be feared. In the spirit of a transubstantiation, the ontological frame that the ontology of war constitutes has directed societies to blame the pandemic on groups outside of one's own community, expelling, or sealing off such groups have been measures that have been undertaken in order to manage anxiety. During the Black Death, Jews were blamed for spreading the disease (Burke 2007), while the Chinese have been made to account for the spreading of the disease during the COVID-19 pandemic (Liu 2020). ${ }^{17}$ An infamous example here is the former president of the US, Donald Trump, who has

\footnotetext{
${ }^{17}$ That Jews were persecuted as a consequence of the Black Death could be connected to a specific political ontology at play in some parts of Medieval Christian Europe during the epidemic in the 14th century. As Claude Lefort has discussed, the theologico-political configuration born of the Medieval Christian societies conceived of social unity "beneath the sign of the spiritual" (Lefort 1988, 229), the Black Death found its natural place in this theologico-political ontology as "a divine scourge, a retribution for the sins of mankind" (Slack 2020, 436). As such the Black Death acted as a powerful moral and political force that wrought down God's wrath on those groups that were Other, it "therefore predisposed men to action of various kinds: a search for scapegoats [...] a condemnation of the infected, especially if they were poor or otherwise disreputable" (Slack 2020, 438). As such it should not come as a surprise that "the rhetoric of fear", employed during this time, "reinvigorated a latent anti-Semitism and xenophobia" (Barney and Scheck 2010, 7; for a more detailed discussion see for example; Finley and Koyama 2016). At the same time the Black Death coincided in Christian Europe, with the "the extension of state powers" (Slack 2020,442), a fact stressed also by Silvia Federici who argues that the counter-revolutions triggered by the Black Death led to the first steps taken on the road to the absolute state (Federici 2004, 44-50).
}

been intent on attaching the anxiety to the Chinese. In a White House press briefing (from March 18, 2020) Trump's introductory remarks were on "a war on the Chinese virus." According to him, the virus is originally from China and therefore it is they who are to blame for the spreading of the virus and its consequences.

These ways of framing events and distributing the burdens of guilt have not come into being arbitrarily as the friend-enemydistinction, based on the ontology of war, is a part of the affective ground of these frames. Racism against Asians has since been ramped up in the US but also in Europe, as Wang summarizes "people with Asian faces [have] in Denmark, Italy, France, Germany, Finland, and Estonia experienced multiple forms of xenophobia and discrimination connected with COVID-19", moreover "there is evidence of xenophobic rumors blaming Muslims, Jews, Roma, and refugees for hosting the virus, even culminating in the extreme nationalists advocating for social exclusion" (Wang 2020, 30-31). Over and above Xenophobia in the West, similar results have been discovered in Asia, Latin America, and Africa, where there is growing evidence that the "COVID-19 pandemic is affecting migrants" who have reported on "increasing racism and xenophobia" (Dionne and Turkmen 2020, 221-222).

When subjects are formed through iteration of the frame of the nation state, the subjects are freed from uncertainty because the nation state promises the subjects certainty and control, at least this is the implicit promise delivered to the citizenry. As was discussed earlier, there will always be differing measures of dissent and alternative frames in play, which will lead to variation in how believable such promises of certainty and control seem in the eyes of the citizenry. The content of this promise is echoed strongly by Hobbes' philosophy, where the principal task of the sovereign is precisely to safeguard its subjects, especially from war. The subject, that the framing enacted by the nation state attempts to iterate, acts in this regard all the time as though it was waiting for the nation state to protect the subject from the dangers of war. The impossibility of neatly localizing the virus within the frame of the friend-enemy-distinction offered by the sovereign nation state's political ontology produces unclarity in the relation between sovereign and subject. Leaning on Zevnik's (2017, 189) theory it is possible to argue that this unclarity, which concerns the feasibility of the sovereign's claim to protect the subject, will push the subject to act as the subject would expect the sovereign to act: it will make the subjects exercise control in regard to each other and demand ever stricter restrictions. The aforementioned way of controlling uncertainty through enmity now shifts in the direction of a confrontation between citizens. The subject's fantasy of the unlimited scope of sovereign power, which is born of the powerlessness of the singular nation state in the face of the virus, makes the subjects reproduce and re-enact the sovereign's potentially unlimited use of power, which can for example be seen in the urge to control other citizens and the hopes and calls for more effective restrictive measures. This kind of dynamic testifies to the fact that managing uncertainty is not only about localizing the enemy; it is also used as a measure to control friends, as the aforementioned need for control between 
citizens shows. Leaning on the recognizability that the war against the virus activates thus generates both unity and a way to use power that are characteristic for the nation state.

The nation states have however provoked open dissent because of their employment of restrictions and protective measures. There has of course been an abundance of citizens calling out the government for failing to deal with the pandemic by not imposing more or tighter restrictions, very visibly in India and the US for example, but there have also been waves of antilockdown protests across the US and Europe. The salient feature of the anti-lockdown protests is that the protesters take aim at the legitimacy of the state as a political actor itself, as Gerbaudo writes "the key grievance mobilized in anti-lockdown protests is the very condition of the lockdown", the "protesters participating in these events claimed that lockdown measures were not motivated by defense of the public good, but were rather a manifestation of a conspiracy" (Gerbaudo 2020, 68). In many of the anti-lockdown protests there appears to be a disconnect between the state as the sovereign actor facing down the pandemic, and the frame of war. The latter seems to be present, taking as its target some version of the state, which leads to the state becoming the target of hostility, an object to fear and resent. Construing the state as the enemy could, in the case of anti-lockdown protests, thus be understood to be another object to be feared in order to fend off anxiety. The libertarian anxieties take on the state as an object of fear because of its restrictive power over the individual. But as Bratich has shown, such libertarian sentiments behind anti-lockdown protests often are also congruent with the logic of the mobilization that the nation state enacts when it shifts the target of the virus to the person who is other. As Bratich exemplifies, "this sentiment was found in the Texas lieutenant governor's infamous line 'There are more important things than living, and that's saving this country for my children and my grandchildren and saving this country for all of us."', here "the 'us' [...] is an extension of 'my,' invoking blood (family) and soil (nation), while predicated on 'the exclusion or subordination of those outside"' (Bratich 2021, 258). This would mean that even if the action of the state or the state itself is felt to be illegitimate from the perspective of this framing, the ontology of war still exerts its grip on the affects of citizens.

The ontology of war present in this general libertarian affective attunement behind many of the anti-lockdown protests is supercharged in those cases where it is backed up with "conspiracies about a "deep state" and an apparent new convergence among anti-government groups across the political spectrum-including anti-vaxxers and flat Earthers, QAnon conspiracy theorists, guns' rights advocates, patriot militias, and White supremacist extremists" a concoction that creates a "combustive mix that brings a high risk of serious violence" (Woods et al., 2020, 817). It would seem plausible to argue that as these kinds of anti-statist conspiracy theories have at their core an understanding of the "deep state" as the de facto locus of power, they can be seen as another try at alleviating the anxiety that is reactivated when the framing of the pandemic by the nation state is experienced to misfire. However, in these cases, the object of fear is constituted as the "state within the state", that tries to hurt the people by imposing draconian restrictions, implanting microchips in people during vaccination and so on. Here the people are put into war with the "deep state", instead of being the national subjects of the state in war with other nonnationals. A political ontology constructing an antagonism in relation to "the deep state" has been extremely visible in the protests in the US, a reason for this could have been the fact that Trump continuously downplayed the importance of the virus which gave credit to the demonstrators' claims about the virus not being dangerous, while lockdown measures were simultaneously being imposed by other government levels, leading to a more complex target for the dissent. As has been noted by for example Pantucci and Ong, 2021 the "propaganda linked to COVID-19" that these antistatist groups disseminate "has focused on racist, anti-Semitic, and other tropes" (6), the consipracies that these fringe groups focus on as objects of fear often seem to involve xenophobic elements. The affective attunements behind many of the anti-lockdown protests thus simultanously seems to lead to a questioning of the legitimacy of the state, framing it as an object of fear, while at the same time being implicated in the same kind of xenophobic outlook that the ontology of war leads to in state-centric accounts as well.

Our discussion poses an obvious ethical and political issue that brings us back to Butler's theory. As Butler emphasises, the recognizability of certain subjects is always partial: "The frame never quite determined precisely what it is we see, think, recognize, and apprehend. Something exceeds the frame that troubles our sense of reality; in other words, something occurs that does not conform to our established understanding of things." (Butler 2009, 9.) It is especially during the pandemic that we have come to see the limits of the political ontology of war as a basis for distinguishing those to be protected and those left without protection. The traditional state system might have helped us buy time to understand the situation, but ultimately all frames, like Butler points out, are partial and they are all the time being transcended. In the last section of our article, we will discuss some takeaways of our analysis. It is not our task here to speculate on the different ways that we could reorganize the basis of our political communities in a way that does not try to establish uniformity by means of locating an enemy. We simply want to point out that our present political ontology is a terrible foundation for governing during a pandemic.

\section{CONCLUDING THOUGHTS}

The pandemic has brought to light the profoundly sad situation we are in, the nation state seems to be unable to allocate resources and work for the common good without any other pretext than war. The frame of war that the nation state puts into action thus reveals the significant inadequacy of the political ontology that the nation state rests on, especially so concerning the failure of this frame to capture the central problematic of the virus. What the political ontology of war amounts to is a splitting up of the world into several unified bodies of subjects, closed off and walled in by the anxietymanaging operations of the nation state. Concerning this relationship between sovereignty, territory and bodies, Butler notes that: 
If we accept the insight that our very survival depends not on the policing of a boundary-the strategy of a certain sovereign in relation to its territory-but on recognizing how we are bound up with others, then this leads us to reconsider the way in which we conceptualize the body in the field of politics. We have to consider whether the body is rightly defined as a bounded kind of entity. (Butler 2009, 52.).

In the spirit of this ethos, the pandemic has underscored the urgency of undertaking a sustained reflection concerning the political ontology structuring our political subjectivity as well as the relations between territories, sovereignties and bodies, both physical and political, that this ontology produces. We know that the virus does not stop at the border of any state. We know that the solution to the pandemic cannot be a total closure of all nation states for eternity, even though this might be the latent claim and desire communicated through the political ontology of war. We also know that we cannot, and should not, desire an extension of the political ontology of the nation state to the whole globe. These seemingly commonsensical statements should be taken to structure the coming theoretical and practical work that remains to be done and redone concerning the complex interwoven character of political bodies and subjects.

As we construe it, the political problem posed by the pandemic is not only rhetorical; it concerns the organization of politics in our societies. It is rather the framing of the pandemic as something other than war that seems tempting and that calls on us to think about the political ontology of the political community and its structures in a way that contests the political ontology of the nation state. In other words, an analysis that takes note of political ontology will lead us to notice how the rhetoric of war is not our primary problem, instead we should focus on more fundamental historical and social structures, the feelings that anchor actors to these structures and the ways in which the political praxis of the nation state is organized. In the political sphere, it is not possible to direct affective expectations, desires and fantasies towards the virus. Especially such expectations, desires and fantasies that are grounded on hatred can within the frame of the political ontology of the nation state only be directed against other humans. We are not able to feel hatred towards the virus by leaning on our political ontology, it is instead perceived through the frame of the network of meanings that the nation state's political ontology of war leans on. This hatred that fantasises about war, has often been understood (see for example Castoriadis 1991, 150-151) to stem from narcissistic self-hatred and is directed towards the outside along the axes provided by the friend-enemy-distinction and is founded on a feeling that one wants others to be the same as oneself. As we have argued the friend-enemy-distinction fails to structure us as subjects at war with the virus and instead structures us as subjects at war with other peoples. As Butler notes concerning the ontology of the nation state: "Lives are divided into those representing certain kinds of states and those representing threats to state-centered liberal democracy". (Butler, 2015, 54.). In this way, the ontology of war also creates a moralistic and antagonistic position in relation to other nationalities.

According to Butler, the political ontology of war carries out a binary division between subjects, where the protection of some subjects is justified at the expense of others (Butler 2009, 31; 54).
A highly urgent development that proves Butler's point is the tendency of what often has been called "vaccine nationalism", the thought that one's own nation should have priority access to the vaccine at the expense of other nations. The discussions concerning the distribution of vaccines display the full force of the political ontology we in this article have analyzed, the question of obtaining vaccines has also been framed through the ontology of war as an "arms race" (see for example Evening Standard 2020; Fortune 2020; New York Times 2020). That the vaccine produced in Russia is called Sputnik, a throwback to a cold-war era imperialism, reveals how even the object that is the vaccine becomes a vessel of nationalistic pride. The basic argument in defense of vaccine nationalism has been presented by Ferguson and Caplan, as they argue that the argument for a self-interested vaccine nationalism is morally justified because of one's primary commitment to one's own nation (Ferguson and Caplan 2020, 1-4). Needless to say, it is "epidemiologically self-defeating and clinically counterproductive" (Foreign Policy 2021) to defend vaccine nationalism in the case of COVID-19, and it might even ultimately work against the purported self-interest of the nation state. However, vaccine nationalism-in line with our argument-is a course of action that dominates the vaccine politics of the US (see Bollyky and Bown 2020) and "other countries-including China, India, the United Kingdom, and members of the European Union" (Fidler 2021, 749).

The border between us and others, inherent to our institution of political ontology, can however also be conceptualized in a way that highlights the fragility of this border, our survival is always dependent on others (Butler 2009, 44; 54). According to Butler, no singular body can be understood to be self-sufficient, bodies are always dependent on others. Butler's conception of the ultimate impossibility of localizing borders that would define who the survival of any one singular body is dependent on is in stark contrast with the theory of sovereignty, where the body gives itself to be protected against the enemy in accordance with the ontology of war (2020, 49; 62). The pandemic testifies to the flickering character of drawing such borders, and even for its impossibility. To end on an illustrative example: ridding the world of smallpox required societies to transgress the borders and the frame of the ontology of war and to notice that a politics that seeks to counter a virus requires political action that rises above antagonism. ${ }^{18}$

\section{AUTHOR CONTRIBUTIONS}

All authors listed have made a substantial, direct, and intellectual contribution to the work and approved it for publication.

\footnotetext{
${ }^{18}$ Here, some forms of international institutions that wield biopower might be more suitable. This is because biopower targets populations instead of citizens bound within territorial borders (Foucault 1976, 183; Foucault 1997, 216-217; Foucault 2004, 13, 22-23; Oksala 2013, 321; Lemke 2019, 96-97, 135; Erlenbusch-Anderson 2020, 12, 20). The limits of a population, especially during a pandemic, are very different from the limits of nation states. It might be that the development of international travel has made humanity into a single population in need of international practies of biopower.
} 


\section{FUNDING}

One of the author's (Tuukka Brunila) has received funding of the Academy of Finland to conduct the his part of the research under the Centre of Excellence in Law, Identity and the European Narratives, funding decision number 312430.

\section{REFERENCES}

Agamben, G. (1998). Homo Sacer. Stanford: Stanford University Press.

Albertson, B., and Gadarian, S. (2015). Anxious Politics. Cambridge: Cambridge University Press. doi:10.1017/cbo9781139963107

Allespach, H., Diaz, Y., and St Onge, J. E. (2020). Regaining Balance during 'reality Vertigo': Six Insights Gleaned from the Front-Line to Manage PandemicRelated Anxiety. Postgrad. Med. J. 96, 369-370. doi:10.1136/postgradmedj2020-137825

Alyeksyeyeva, I., Kaptiurova, O., and Orlova, V. (2021). World War Flu: War Rhetoric of the Australian Prime Minister on Coronavirus. 3l 27, 90-101. doi:10.17576/3L-2021-2701-07

Arendt, H. (1969). On Violence. New York: Harcourt, Brace \& World.

Balakrishnan, G. (2000). The Enemy: An Intellectual Portrait of Carl Schmitt. London: Verso. doi:10.1007/978-1-4612-1334-5

Balke, F. (2005). Derrida and Foucault on Sovereignty. Ger. Law J. 6, 71-85. doi:10.1017/S2071832200013481

Barney, R. A., and Scheck, H. (2010). Introduction: Early and Modern Biospheres, Politics, and the Rhetorics of Plague. J. Early Mod. Cult. Stud. 10, 1-22. doi:10.1353/jem.2011.0002

BBC (2020). Biden Thanksgiving Speech: We're at War with the Virus, Not Each Other. Available at: https://www.bbc.com/news/election-us-2020-55078066 (Accessed February 28, 2021).

Bieber, F. (2020). Global Nationalism in Times of the COVID-19 Pandemic. Nationalities Pap., 1-13. doi:10.1017/nps.2020.35

Bollyky, T., and Bown, C. (2020). The Tragedy of Vaccine Nationalism. Foreign Aff. 99, 96-100.

Bourke, J. (2007). Fear: A Cultural History. Berkeley: Counterpoint.

Bratich, J. (2021). 'Give Me liberty or Give Me Covid!': Anti-lockdown Protests as Necropopulist Downsurgency. Cult. Stud. 35, 257-265. doi:10.1080/ 09502386.2021 .1898016

Butler, J. (2009). Frames of War: When Is Life Grievable?. London: Verso.

Butler, J. (2015). Senses of the Subject. New York: Fordham University Press.

Butler, J. (2020). The Force of Nonviolence: An Ethicopolitical Bind. London: Verso.

Castoriadis, C. (1991). Philosophy, Politics, Autonomy. Oxford: Oxford University Press.

Chambers, S., and Carver, T. (2008). Judith Butler and Political Theory. London: Routledge. doi:10.4324/9780203937440

Cocks, J. (2014). On Sovereignty and Other Political Delusions. London: Bloomsbury Publishing.

Cossarini, P. (2017). "Indignation as Resistence: Beyond the Anxiety of No Future Alternatives," in The Politics of Anxiety. Editors E. Eklundh, A. Zevnik, and E-P. Guittet (Toronto: Rowman \& Littlefield), 141-164.

Dagens Arena. (2020). Militariseringen Av Covid-19. Available at: https://www. dagensarena.se/essa/militariseringen-av-coronapandemin/ [Accessed June 29, 2021]

de Lagasnerie, G. (2020). Foucault against Neoliberalism?. London: Rowman \& Littlefield. doi:10.1515/9781503605794

Derrida, J. (2003). La Raison du Plus Fort. Le Monde diplomatique. Available at: https://www.monde-diplomatique.fr/2003/01/DERRIDA/9835 [Accessed February 20, 2021]

Derrida, J. (2005). Politics of Friendship. London: Verso.

Dionne, K. Y., and Turkmen, F. F. (2020). The Politics of Pandemic Othering: Putting COVID-19 in Global and Historical Context. Int. Org. 74, E213-E230. doi:10.1017/S0020818320000405

Ditrych, O. (2013). From Discourse to Dispositif: States and Terrorism between Marseille and 9/11. Security Dialogue 44, 223-240. doi:10.1177/ 0967010613484076

\section{ACKNOWLEDGMENTS}

The authors are grateful to Senni Mut-Tracy for helping with the searching of relevant research literature. The authors wish to thank Emilia Palonen for giving us the opportunity to write this article in the special issue

Eklundh, E., Zevnik, A., and Guittet, E-P. (2017). "Introduction: The Politics of Anxiety," in The Politics of Anxiety. Editors E. Eklundh, A. Zevnik, and E-P. Guittet (Toronto: Rowman \& Littlefield)), 1-14.

Erlenbusch-Anderson, V. (2020). The Beginning of a Study of Biopower: Foucault's 1978 Lectures at the Collège de France. $f_{s l} 3$ (1), 5-26. doi:10.22439/fsl.vi0.6151

Esch, J. (2010). Legitimizing the "War on Terror": Political Myth in Official-Level Rhetoric. Polit. Psychol. 31, 357-391. doi:10.1111/j.1467-9221.2010.00762.x

Evening Standard. (2020). Vaccine Arms Race: How the Competition for a Covid Jab Is Heating up. Available at: https://www.standard.co.uk/news/health/ coronavirus-vaccine-competition-race-b77116.html [Accessed February 20, 2021].

Eysenck, M. (1992). Anxiety: The Cognitive Perspective. London: Psychology Press. Falk, F. (2011). Hobbes' Leviathan und die aus dem Blick gefallenen Schnabelmasken. Leviathan 39, 247. doi:10.1007/s11578-011-0117-y

Federici, S. (2004). Caliban and the Witch. Autonomedia: Williamsburgh.

Ferguson, K., and Caplan, A. (2020). Love Thy Neighbour? Allocating Vaccines in a World of Competing Obligations. J. Med. Ethics 2020, 106887. medethics J Med Ethics [Preprint]. doi:10.1136/medethics-2020-106887

Fidler, D. P.. (2020): Vaccine Nationalism's Politics. Science 369, 749. doi:10.1126/ science.abe2275

Finley, T. S., and Koyama, M. (2016), Plague, Politics, and Pogroms: The Black Death, Rule of Law, and the Persecution of Jews in the Holy Roman Empire, SSRN J. Paper No. 16-19. doi:10.2139/ssrn.2761524

Foreign Policy. (2021). Vaccine Nationalism Harms Everyone and Protects No One. Available at: https://foreignpolicy.com/2021/02/02/vaccinenationalism-harms-everyone-and-protects-no-one/[Accessed February 28, 2021]

Forsberg, T. (2020). Sodassa koronavirusta vastaan? COVID-19 ja metaforien pandemia. Kosmopolis 50, 104-115.

Fortune. (2020). The COVID Vaccine Arms Race and the Struggles of the Supply Chain. Available at: https://fortune.com/2020/08/20/the-covid-vaccine-armsrace-and-the-struggles-of-the-supply-chain/ [Accessed 20 February 2021].

Foucault, M. (1976). Histoire de la Sexualité : La Volonté de Savoir. Paris: Gallimard.

Foucault, M. (1997). Il faut défendre la société: Cours au Collège de France, 1975 1976. Paris: Gallimard/Seuil.

Foucault, M. (2004). Sécurité, territoire, population: Cours au Collège de France, 1977-1978. Paris: Gallimard/Seuil.

Foucault, M. (1975). Surveiller et punir: Naissance de la prison. Paris: Gallimard.

Freeman, L., and Elpidorou, A. (2020). "Fear, Anxiety and Boredom," in The Routledge Handbook of Phenomenology of Emotions. Editors T. Szanto and H. Landweer (New York: Routledge), 392-402. doi:10.4324/ 978131518078610.4324/9781315180786-38

Gerbaudo, P. (2020). The Pandemic Crowd. J. Int. Aff. 73, 61-76.

Gros, F. (2019). The Security Principle: From Serenity to Regulation. London: Verso. doi:10.1007/978-3-658-24947-2

Groulx, R. (2015). Michel Foucault, la politique comme guerre continuée. Paris: L'Harmattan.

Helmisaari, V. (2020). Thomas Hobbes and Contemporary Italian Thinkers : Permanent War in Giorgio Agamben, Roberto Esposito and Antonio Negri. [Helsinki: University of Helsinki. dissertation.:]:

Hirvonen, A. (2017). Fear and Anxiety: The Nationalist and Racist Politics of Fantasy. L. Critique 28, 249-265. doi:10.1007/s10978-017-9210-y

Hobbes, T. (2018). Leviathan. Cambridge NY: Cambridge University Press.

Huddy, L., Feldman, S., Taber, C., and Lahav, G. (2005). Threat, Anxiety, and Support of Antiterrorism Policies. Am. J. Polit. Sci. 49, 593-608. doi:10.1111/ j.1540-5907.2005.00144.x

Hunt, A. (2009). Anxiety and Social Explanation: Some Anxieties about Anxiety. J. Soc. Hist. 32, 509-528. doi:10.1353/jsh/32.3.509 
Kennedy, E. (2004). Constitutional Failure: Carl Schmitt in Weimar. Durham NC: Duke University Press. doi:10.1515/9780822385578

Kennedy, E. (1998). "Hostis Not Inimicus:", in Law as Politics: Carl Schmitt's Critique of Liberalism. Editor D. Dyzenhaus (London: Duke University Press), 92-108. doi:10.2307/j.ctv1 1hpj9h.9

Kervégan, J.-F. (2011). Que faire de Carl Schmitt?. Paris: Gallimard.

Kierkegaard, S. (1981). The Concept of Anxiety. Princeton: Princeton University Press.

Kinnvall, C. (2004). Globalization and Religious Nationalism: Self, Identity, and the Search for Ontological Security. Polit. Psychol. 25, 741-767. doi:10.1111/j.14679221.2004.00396.x

Kinnvall, C., and Mitzen, J. (2020). Anxiety, Fear, and Ontological Security in World Politics: Thinking with and beyond Giddens. Int. Theor. 12, 240-256. doi:10.1017/S175297192000010X

Kleiner, S.. (2020). What a Real Wartime President Does. Democracy Journal. Available at: https://democracyjournal.org/arguments/what-a-real-wartimepresident-does/ [Accessed June 29, 2021]

Kleio in Pandemia. (2020). Masked Isolation: The Czech Republic and the Early Coronavirus Response. Available at: https://www.cultures-of-history.unijena.de/focus/kleio-in-pandemia/masked-isolation-the-czech-republic-andthe-early-coronavirus-response/ [Accessed May 14, 2021]

Koskenniemi, M. (2017). Sovereignty, Property and Empire: Early Modern English Contexts. Theor. Inquiries L. 18, 355-389. doi:10.1515/til-2017-0017

Le Monde (2020) Nous sommes en guerre': le verbatim du discours d'Emmanuel Macron. Available at: https://www.lemonde.fr/politique/article/2020/03/16/ noussommes-en-guerre-retrouvez-le-discours-de-macronpour-lutter-contre-lecoronavirus_6033314_823448. [Accessed February 28, 2020]

Ledoux, J. (2016). Anxious. New York: Penguin Random House.

Lefort, C. (1988). Democracy and Political Theory. Cambridge: Polity Press.

Lemke, M. (2020). Deutschland im Notstand? Politik und Recht während der corona-Krise. Frankfurt: Campus Verlag.

Lemke, T. (2019). Foucault's Analysis of Modern Governmentality: A Critique of Political Reason. London: Verso Books.

Liu, A. (2020). Chinese Virus, World Market. There Is No outside: COVID-19 Dispatches. Lontoo: Verso Books.

Liu, C. H., Zhang, E., Wong, G. T. F., Hyun, S., Hyeouk, H., and Hahm, H. C. (2020). Factors Associated with Depression, Anxiety, and PTSD Symptomatology during the COVID-19 Pandemic: Clinical Implications for U.S. Young Adult Mental Health. Psychiatry Res. 290, 113172-113177. doi:10.1016/j.psychres.2020.113172

Lohm, D., Davis, M., Flowers, P., and Stephenson, N. (2015). 'Fuzzy' Virus: Indeterminate Influenza Biology, Diagnosis and Surveillance in the Risk Ontologies of the General Public in Time of Pandemics. Health Risk Soc. 17, 115-131. doi:10.1080/13698575.2015.1031645

Magrini, J. (2006). Anxiety in Heidegger's Being and Time: The Harbinger of Authenticity. Philos. Scholarship 15, 77-86.

Malabou, C. (2015). "Will Sovereignty Ever Be Deconstructed?," in Plastic Materialities: Politics, Legality, and Metamorhopsis in the Work of Catherine Malabou. Editors B. Bhandar and J. Goldberg-Miller (Durham NC: Duke University Press), 35-46. doi:10.2307/j.ctv11cw1jx.5

Markell, P. (2003). Bound by Recognition. Princeton: Princeton University Press.

Massumi, B. (2015a). Ontopower: War, Powers and the State of Perception. Durham NC: Duke University Press. doi:10.2307/j.ctv120qqxv

Massumi, B. (2015b). Politics Of Affect. Cambridge: Polity Press.

Mbembe, A. (2019). Necropolitics. Durham NC: Duke University Press. doi:10.1215/9781478007227

McElroy, E., Patalay, P., Moltrecht, B., Shevlin, M., Shum, A., Creswell, C., et al. (2020). Demographic and Health Factors Associated with Pandemic Anxiety in the Context of COVID-19. Br. J. Health Psychol. 25, 934-944. doi:10.1111/ bjhp. 12470

Meyer, Katrin. (2016). "Der Kreislauf von Macht und Gewalt", in Macht, Aktuelle Perspektiven aus Philosophie und Sozialwissenschaften. Editor P. H. Roth (Franfkurt: Campus Verlag), 45-62.

Moisio, S. (2020). State Power and the COVID-19 Pandemic: the Case of Finland. Eurasian Geogr. Econ. 61, 598-605. doi:10.1080/15387216.2020.1782241

Mouffe, C. (2005). The Return of the Political. London: Verso.

New York Times. (2020). Search for Coronavirus Vaccine Becomes a Global Competition. Available at: https://www.nytimes.com/2020/03/19/us/ politics/coronavirus-vaccine-competition.html [Accessed February 20, 2021].

Nordin, A. H. M., and Öberg, D. (2015). Targeting the Ontology of War: From Clausewitz to Baudrillard. Millennium 43, 392-410. doi:10.1177/ 0305829814552435

Oksala, J. (2012). Foucault, Politics, and Violence. Evanston: Northwestern University Press.

Oksala, J. (2013). "From Biopower to Governmentality," in A Companion to Foucault. Editors C. Falzon, T. O'Leary, and J. Sawicki (Malden, MA: WileyBlackwell)), 320-336. doi:10.1002/9781118324905.ch15

Oksala, J. (2010). Violence and the Biopolitics of Modernity. Fs 10, 23-43. doi:10.22439/fs.v0i10.3122

Pankakoski, T. (2017). Containment And Intensification In Political War: Carl Schmitt And The Clausewitzian Heritage. History of European Ideas 43, 649-673. doi:10.1080/01916599.2016.1234967

Pantucci, R., and Ong, K. (2021). Persistence of Right-wing Extremism and Terrorism in the West. Counter Terrorist Trends Analyses 13, 118-126. doi:10.2307/26979992

Poole, T. (2015). Reason of State: Law, Prerogative and Empire. Cambridge: Cambridge University Press. doi:10.1017/cbo9781316106099

Prozorov, S. (2013). Powers of Life and Death. Alternatives 38 (3), 191-193. doi:10.1177/0304375413497841

Prozorov, S. (2015). Towards a Post-Hobbesian Political Community?. Hobbes Stud. 28, 50-63. doi:10.1163/18750257-02801005

Rafi, M. S. (2020). Language of COVID-19: Discourse of Fear and Sinophobia SSRN J., 1-14. doi:10.2139/ssrn.3603922

Reuters (2020). PM Says Greece at War with 'invisible Enemy' Coronavirus. Available at: https://www.reuters.com/article/us-health-coronavirus-greecepm-idUSKBN2142T5 [Accessed May 5, 2021]

Robbins, P., and Moore, S. A. (2013). Ecological Anxiety Disorder: Diagnosing the Politics of the Anthropocene. Cult. Geographies 20, 3-19. doi:10.1177/ 1474474012469887

Rousseau, J-J. (2008). The Social Contract. Oxford: Oxford University Press.

Rumelili, B. (2020). Integrating Anxiety into International Relations Theory: Hobbes, Existentialism, and Ontological Security. Int. Theor. 12, 257-272. doi:10.1017/S1752971920000093

Sartre, J-P. (2007). Existentialism Is a Humanism. Yale: Yale University Press. doi:10.2307/j.ctv15vwkgx

Scheuerman, W. E. (2017). "States of Emergency," in The Oxford Handbook of Carl Schmitt. Editors J. Meierhenrich and O. Simons (New York, NY: Oxford University Press), 547-569.

Schmitt, C. (1932/2015). Der Begriff des Politischen : Text von 1932 mit einem Vorwort und drei Corollarien. Berlin: Duncker \& Humblot.

Schmitt, C. (1927/1988). Der Begriff des Politischen. Positionen und Begriffe: im Kampf mit Weimar - Gent - Versailles 1923-1939. Berlin: Duncker \& Humblot.

Schmitt, C. (2017). Gespräch über die Macht und den Zugang zum Machthaber. Stuttgart: Klett-Cotta.

Schmitt, C. (1933/1958). Machtpositionen des Modernen Staates. Verfassungsrechtliche Aufsätze aus den Jahren 1924-1954: Materialien zu einer Verfassungslehre. Berlin.

Schmitt, C. (1930). Staatsethik und pluralistischer Staat. Kant-Studien 35, 28-42.

Shams, P. (2020). Judith Butler and Subjectivity. Singapore: Palgrave Macmillan. doi:10.1007/978-981-15-6051-4

Sjölander-Lindqvist, A., Larsson, S., Fava, N., Gillberg, N., Marcianò, C., and Cinque, S. (2020). Communicating about COVID-19 in Four European Countries: Similarities and Differences in National Discourses in Germany, Italy, Spain, and Sweden. Front. Commun. 5, 1-14. doi:10.3389/ fcomm.2020.593325

Slack, P. (2020). Responses to Plague in Early Modern Europe: The Implications of Public Health. Soc. Res. Int. Q. 87, 409-428.

Spadaro, A. (2020). COVID-19: Testing the Limits of Human Rights. Eur. J. Risk Regul. 11, 317-325. doi:10.1017/err.2020.27

Steenbergen, M., and Ellis, C. (2006). "Fear and Loathing in American Elections: Context, Traits, and Negative Candidate Affect," in Feeling Politics: Emotion in Political Information Processing. Editor D. Redlawsk (New York: Palgrave Macmillan), 1-10.

Strang, J. (2020). Why Do the Nordic Countries React Differently to the Covid19 Crisis? Nordics.info. Available at: https://nordics.info/show/artikel/the- 
nordic-countries-react-differently-to-the-covid-19-crisis/ [Accessed June 29, 2021]

Su, R., and Shen, W. (2021). Is Nationalism Rising in Times of the COVID-19 Pandemic? Individual-Level Evidence from the United States. J. Chin. Polit. Sci. 26, 169-187. doi:10.1007/s11366-020-09696-2

Teschke, B. (2016). ““'Carl Schmitt's Concepts of War: A Categorical Failure,", in The Oxford Handbook of Carl Schmitt. Editors J. Meierhenrich and O. Simons (New York, NY: Oxford University Press), 367-400.

Thiem, A. (2008). Unbecoming Subjects : Judith Butler, Moral Philosophy, and Critical Responsibility. New York: Fordham University Press. doi:10.5422/fso/ 9780823228980.001 .0001

Tuck, R. (2001). The Rights of War and Peace: Political Thought and the International Order from Grotius to Kant. Oxford: Oxford University Press on Demand. doi:10.1093/acprof:oso/9780199248148.001.0001

Villadsen, L. (2020). One Word to Rule Them All: 'Civic-Mindedness' and Danish Prime Minister Frederiksen's Nationalist Covid-19 Rhetoric. Punctum. 06, 229-248. doi:10.18680/hss.2020.0030

Wang, Z. (2021). From Crisis to Nationalism?. Chin. Polit. Sci. Rev. 6, 20-39. doi:10.1007/s41111-020-00169-8

Washington Post (2020). The Self-Anointed 'wartime President' Finds a New, More Exciting War. Available at: https://www.washingtonpost. com/politics/2020/06/01/self-anointed-wartime-president-finds-newmore-exciting-war/ [Accessed June 29, 2021]

Weiss, M. (2012). "Introduction: Fear and its Opposites in the History of Emotions," in Facing Fear. Editors L. Michael and M. Weiss (Princeton: Princeton University Press), 1-9. doi:10.1515/9781400845248-002
White House (2020). Press Briefing 18.3.2020. Available at: https://www.whitehouse. gov/briefings-statements/remarks-president-trump-vice-president-pencememberscoronavirus-task-force-press-briefing-5/ [Accessed February 28, 2021]

Woods, E. T., Schertzer, R., Greenfeld, L., Hughes, C., and Miller-Idriss, C. (2020). COVID19, Nationalism, and the Politics of Crisis: A Scholarly Exchange. Nations and Nationalism 26, 807-825. doi:10.1111/nana.12644

Young-Bruehl, E. (2008). Why Arendt Matters. Yale: Yale University Press.

Zevnik, A. (2017). From Fear to Anxiety: An Exploration into a New Socio-Political Temporality. L. Critique 28, 235-246. doi:10.1007/s10978-017-9211-x10.1007/s10978-017-9211-x

Conflict of Interest: The authors declare that the research was conducted in the absence of any commercial or financial relationships that could be construed as a potential conflict of interest.

Publisher's Note: All claims expressed in this article are solely those of the authors and do not necessarily represent those of their affiliated organizations, or those of the publisher, the editors and the reviewers. Any product that may be evaluated in this article, or claim that may be made by its manufacturer, is not guaranteed or endorsed by the publisher.

Copyright (c) 2021 Lehtinen and Brunila. This is an open-access article distributed under the terms of the Creative Commons Attribution License (CC BY). The use, distribution or reproduction in other forums is permitted, provided the original author(s) and the copyright owner(s) are credited and that the original publication in this journal is cited, in accordance with accepted academic practice. No use, distribution or reproduction is permitted which does not comply with these terms. 